\title{
SYMPOSIUM ON \\ THE INTERNATIONAL LEGAL OBLIGATION TO CRIMINALIZE MARITAL RAPE
}

\author{
"IF YOU BUY A CUP, WHY WOULD YOU NOT USE IT?" \\ MARITAL RAPE: THE ACCEPTABLE FACE OF GENDER BASED VIOLENCE
}

\author{
Fareda Banda*
}

There are cases that one never forgets. DPP $v$. Morgan is one of those for me. ${ }^{1} \mathrm{I}$ read it as an eighteen-yearold in my first year of law school. It was in the criminal law class where we were being taught about rape. The facts left me shocked and outraged. Morgan went out drinking with his friends. At the end of the night, he invited the friends back to his house. He told them that they could have sex with his wife and added that they should not worry if she appeared to resist, because she liked it that way. The friends duly came over and helped themselves to his wife as per his instructions. Morgan also forced her to have sex with him despite her protestations. She experienced injuries which necessitated medical treatment. His friends were convicted of rape, but he was convicted of indecent assault. This seemed strange. Had they all not forced her to have sex with them despite her clearly expressed refusal? Why was he charged with a lesser crime? The reason was simple: he was her husband. Under the law as it then operated in England, there was no recognition of marital rape. Her consent to lifelong sex on demand, even if it was against her will, was taken as part of the contract of marriage. The words "I do" spoken at the time of the marriage, were taken to mean free access for the husband for as long as they both lived, or until the marriage was legally dissolved or a formal separation was in place.

Despite normative progress on gender-based violence at the international and regional level, discussed by Randall and Venkatesh in their essay in this symposium, marital rape remains a problem globally. ${ }^{2}$ As they note, nonconsensual sex in marriage constitutes gender-based violence, which has been defined by the Committee on the Elimination of All Forms of Discrimination against Women (CEDAW) as: "violence that is directed against a woman because she is a woman or that affects women disproportionately. It includes acts that inflict physical, mental or sexual harm or suffering, threats of such acts, coercion and other deprivations of liberty."3

* Professor of Law, SOAS, University of London.

Originally published online 17 May 2016.

${ }^{1}$ DPP v. Morgan [1976] AC 182 (HL).

2 Melanie Randall \& Vasanthi Venkatesh, Criminalizing Sexual Violence against Women in Intimate Relationships: State Obligations Under Human Rights Law, 109 AJIL UnBOUND 189, 190 (2015).

${ }^{3}$ Comm. on the Elimination of Discrimination Against Women, General Recommendation 19, para. 6, UN Doc. A/47/38 (1992). 
Rationales for Tolerating Marital Rape

Wifely consent to sexual intercourse with her husband has been, and continues to be, embedded in many societies within the marital contract by common law, religion (including obedience laws and the invocation of the notion of the "submissive wife"), and, finally, customary law. 4 The Personal Status Act of Yemen of 1992, for example, reinforces the idea that the marital contract is based on wifely obedience:

Article 40. A husband has the right to be obeyed by his wife in the interest of the family, especially in regard to the following:

1. She must move with him to the conjugal home, unless she has stipulated in the marriage contract that she must remain in her own home or her family's home, in which case she must permit him to live with her and have access to her;

2. She must permit him to have legitimate intercourse with her when she is fit to do so. (emphasis added)

In patrilineal societies in parts of Africa, men convey gifts/bride wealth to the families of their future wives. ${ }^{5}$ This is for three reasons: the first is to secure the "right" of the husband to have the children belong to his family line (genetrical rights), the second is to secure exclusive sexual access to the woman (uxorial rights), and the third is to compensate the family of origin for the transfer of the woman's labour to the husband's family. It is in the claim to uxorial rights that the problem of marital rape arises. For some men, the giving of bride wealth acts as a down payment for sex on demand. A Ugandan man who was asked about his views on marital rape asked quizzically: "Why would you buy a cup and not use it?"6 The idea of rape within marriage was, for him, a nonsense. CEDAW has described bridewealth as a harmful practice in its dialogue with the government of Uganda.7 Significantly, it also expressed concern about the "high prevalence of domestic violence" and of "sexual offences against women and girls." 8

The idea of bridewealth giving rise to, or being used to justify, gender-based violence was raised by Mifumi, a Ugandan women's advocacy group, in its partly-successful appeal to the Constitutional Court to outlaw the practice as a violation of women's rights. In Mifumi v. Attorney General, the Court refused to link bridewealth to violence against women, noting that gender-based violence was a global phenomenon not confined to Uganda. ${ }^{9}$ Such violence also happens in places where no bridewealth is paid. The court did however declare that the requirement that the wife's family return a portion of the bridal gift if she wanted a divorce was indeed a breach of the Constitution's guarantee of gender equality and should be struck down. This portion of the judgement recognizes that it is economic dependency that ties women to difficult marriages and that removing the repayment requirement will go some way to freeing those women who want to leave their unions.

The importance of this refusal to recognize the link between bridewealth and gender-based violence within marriage can be seen by looking at The Muslim Personal Law Act of Sudan (1991), which provides in Section 91 that:

\footnotetext{
${ }^{4}$ The nonrecognition of same sex marriage in many societies means that the crime is still conceived in heteronormative terms. Indeed, it is telling that it is in those societies that are most resistant to permitting same sex marriages, or indeed recognizing the rights of same sex people, that still permit husbands to rape their wives.

5 The exchange of gifts is known by different names including lobolo, bogadi, (Southern Africa) ti-aseda (Akans), idana (Yoruba), mabari (Swabili) ikpo onu aku nwayi (Yoruba).

${ }^{6}$ CHANGE, Non Consensual Sex in Marriage, Marriage, Culture and Violence: Messages from the Survey (2002).

${ }^{7}$ CEDAW, Concluding Observations: Uganda, para. 20, UN Doc. CEDAW/C/UGA/CO/7 (Oct. 22, 2010).

${ }^{8} \underline{I d}$. at para. 23.

${ }^{9}$ Mifumi (U) v. Attorney-General, [2015] UGSC 13 (Uganda).
} 
Except in situations involving a violation of Shari'a law, a wife shall always obey her husband if he:

(a) has paid her dowry in full,

(b) could be entrusted with her, and

(c) provides her with a home that complies with the Shari'a requirement among good neighbors. (emphasis added).

Section 92 goes on to say that, "[i]f the wife refuses to obey her husband, her right to be provided with a living ceases to be valid during such refusal." 10

Research undertaken in different African states seems to suggest that women internalize their "duty" to have intercourse with their husbands on demand so that they do not always conceive of coercive sex as illegal. They see it, rather, as part of the marital bargain that they struck, or that their relatives struck on their behalf. ${ }^{11}$

While the marital rape exemption was overturned in England in 1992, it remains, like homophobic laws also exported by the British, in place in many former colonies. The Bahamas is one such state. Its Sexual Offences and Domestic Violence Act (1991) provides in Section 3 that "[r]ape is the act of any person not under fourteen years of age having sexual intercourse with another person who is not his spouse." The statute further clarifies that consent will be vitiated when: "impersonating the spouse of that other person." 12 The husband's proprietal rights in the wife and her body are reinforced by the impersonation clause.

Marriage adds a new dimension to sexual coercion. It comes freighted with expectation of love, security, and support. What then is a woman to do, if instead, it becomes the source of terror? Who does she tell if telling is the equivalent of exploding the marriage? How much harder is it if there are children, if one belongs to a church community, if one had a big wedding, if everyone thinks he is a great guy, if you would lose face, or worse, your family would be embarrassed if this became public? All these factors help to explain why it is that the few recorded marital rape cases that exist were brought after the couple had separated. ${ }^{13}$ Indeed, Roman Dutch law, the legacy of which is still to be found in former Dutch colonies and their neighbours, used to require the couple to have separated before a marital rape claim could be brought. ${ }^{14}$

\section{Perversions: Rape Leading to Marriage}

Marital rape is but one manifestation of on-going, pervasive, gender-based violence that affects women in most societies. Sometimes rape can be used as the precursor to marriage. There are capture marriages where a man abducts a woman and keeps her from her family, sometimes raping her and "making her his wife." In conservative societies that prize virginity as a condition of marriage, a woman violated in this way may feel compelled to remain with the man as his wife, enduring a lifetime of violation. ${ }^{15}$ Although the Human Rights Committee has condemned this practice and called for its eradication, it continues. ${ }^{16}$ According to Equality

10 The Muslim Personal Law Act of Sudan, 1991, EQuALITY Now.

11 Gathered in Fareda Band, Women, Law And Human Rights: An African Perspective 172-176 (2005).

12 The Sexual Offences and Domestic Violence Act, 1991 (Bah.), EQuAlity Now.

13 There are still jurisdictions that permit religious tribunals to pronounce on divorce. This may result in a woman relying on the rapist-husband to release her from their contract of marriage.

${ }^{14}$ H v. H 1999 (2) ZLR 358 (Zim.).

15 South African Law Reform Commission, The Practice of Ukuthwala, Revised Discussion PAPer 138 (2015); Chelete Monyane, $\underline{I s}$ Ukuthwala another form of 'Forced Marriage'?, 44 S. AFR. REV. SOC. 64 (2013).

${ }_{16}$ UN Human Rights Comm., General Comment 28, Equality of Rights Between Men and Women (Article 3), para. 24, UN Doc. CCPR/C/21/Rev.1/Add.10 (2000). 
Now: "Sections 199(1) and 200 of Malta's Criminal Code reduce the penalty for abduction if the perpetrator intends to marry the victim on abduction and exempts the perpetrator from prosecution and punishment if that person does in fact marry the person abducted."17

Article 522 of Lebanon's Penal Code stops prosecution or execution of a penalty when the perpetrator of a rape, kidnapping, or statutory rape marries the person he has raped or kidnapped. ${ }^{18}$

In privatizing violence in this way, there is an abrogation of the state responsibility of due diligence which includes prosecuting and punishing offenders. Rape statutes that allow marriage in mitigation reward violence. There is also a total ignorance about the systemic and structural discrimination that forces women to "consent" to marry their rapists—a reinforcement of gendered inequalities. ${ }^{19}$

\section{The Need for a Holistic Approach}

Given structural inequalities, amending the laws to penalize marital rape is at best a partial solution. Perhaps more important than calling for such criminalization is the call made by feminist scholars who have advocated for a more holistic, transformative model of equality that tackles structural discrimination. ${ }^{20}$ CEDAW has stressed the importance of such a model. While the Committee thus recognizes the importance of removing discriminatory legislation which permits marital rape, it also calls upon states to encourage their populations to change attitudes using education and other means. A brief glance at cases pertaining to violence against women that have been considered by the Committee under its Optional Protocol shows that it focuses on gender stereotyping as both cause and consequence of the violence that is the subject of the complaint. The Committee regularly cites Article 5(a) on states' obligations to "modify the social and cultural patterns of conduct of men and women, with a view to achieving the elimination of prejudices and customary and all other practices which are based on the idea of the inferiority or the superiority of either of the sexes or on stereotyped roles for men and women." The case of Vertido v. Philippines concerned a woman who had been raped by a work colleague. She had reported the rape but had been met by disbelief by police and medical personnel. At trial, the judges invoked rape myths about the expected behaviour of a "proper" rape victim. The appeal to the CEDAW Committee was to challenge this stereotyping. Finding in her favor, the Committee requested the state to:

Ensure that all legal procedures in cases involving crimes of rape and other sexual offenses are impartial and fair, and not affected by prejudices or stereotypical gender notions. To achieve this, a wide range of measures are needed, targeted at the legal system, to improve the judicial handling of rape cases, as well as training and education to change discriminatory attitudes towards women. ${ }^{21}$

${ }^{17}$ Criminal Code (Malta), Equality Now. Equality Now notes that while Article 308 of the Palestinian Penal Code No. 16 of 1961 also exempts a perpetrator of rape, kidnapping, and statutory rape from prosecution and punishment if he marries his victim, it retains the possibility of reviving the prosecution.

${ }^{18}$ The Penal Code (Leb.), Equality Now.

${ }^{19}$ Criminal Code (Malta), EQuality Now.

${ }^{20}$ Rikki Holtmaat, Article 5 , in The UN Convention on the Elimination of All Forms of Discrimination Against Women: A Commentary 141 (Marsha A. Freeman et al. eds., 2013); RebeCCA CoOK \& Simone CusACK, GENDER STEREOTYPING: TRANSNATIONAL LEGAL PERSPECTIVES (2010); OHCHR Gender Stereotyping as a Human Rights Violation (2013).

${ }^{21}$ CEDAW, Vertido v. Phil. Communication No. 18/2008, para. 8(9)(b), UN Doc. CEDAW/C/46/18/2008, (Sept. 1, 2010). See also, CEDAW, A.T. v. Hung, Communication No. 2/2003, UN Doc. CEDAW/32/D/2/2003 (Jan. 26, 2005), CEDAW, Isatou Jallow v. Bulg., Communication No. 32/2011, UN Doc. CEDAW/C/52/D/32/2011 (Aug. 28, 2012). 
More recently the Committee has added a General Recommendation on Access to Justice, in recognition of the barriers (not just legal but also institutional, social, cultural, and economic) that face women seeking to vindicate their rights. ${ }^{22}$

The refusal of many states to outlaw marital rape in breach of human rights obligations voluntarily undertaken speaks to a disregard for women and reinforces unequal power relations within marriage. Instead such states choose to use the right to privacy and "family harmony" as the reasons for not protecting women. Criminalizing rape in marriage is a start. Equally important is making provision for separation and divorce without sacrificing financial support. Women's economic dependency explains why, for many, marriage remains the only career option. Its sustenance, at any cost, including rape, is often the price paid..$^{23}$

What is required is transformative equality that goes beyond legal change to take in attitudes. With this in mind, the answer to the question the Ugandan man is alleged to have asked: "Why would you buy a cup if you could not use it?" is simple; women are people not cups.

22 CEDAW, General Recommendation 33, UN Doc. CEDAW/C/GC/33, (July 23, 2013).

${ }^{23}$ See for example the Democratic Republic Law 87-010 on the Family Code which gives the husband marital power over the wife including controlling her property, movements, and deciding where the family is to live, Law 87-010 on the Family Code (Dem. Rep. Congo), EQuAlitY Now. 